\title{
The Impact of Tax Rates on Economic Growth of Iran in the Years 1981-2010
}

\author{
Mohsen Dehghan ${ }^{1}$, Masood Nonejad ${ }^{2, *}$ \\ ${ }^{1}$ VAT Department, the Tax Administration, Fars, Iran \\ ${ }^{2}$ Economic and Management Faculty, Islamic Azad University of Shiraz, Shiraz, Iran
}

Email address:

Mohsen_d9@yahoo.com (M. Dehghan),mnonejad.iaushiraz@yahoo.com (M. Nonejad)

\section{To cite this article:}

Mohsen Dehghan, Masood Nonejad. The Impact of Tax Rates on Economic Growth of Iran in the Years 1981-2010. Journal of Finance and Accounting. Vol. 3, No. 6, 2015, pp. 220-226. doi: 10.11648/j.jfa.20150306.18

\begin{abstract}
Several studies have shown that the country economy is based on oil and fossil fuel based, very vulnerable to factors such as war and sanctions. In recent years the Iranian government is trying to reduce dependence on oil and expanding the tax revenue. In this study the use of tax revenues, the effect of three types of tax rates including corporate tax rate, business tax rate and indirect taxes rate (each share of taxes in GDP) on economic growth in Iran during the Thirty Years' 1981-2010 with using of Auto Regressive Distributed Lags (ARDL) examined. In addition to these three variables, other variables such as annual population growth rate, inflation rate and degree of trade openness on economic growth is examined. The results suggest that the impact of the increase in the rates of these three types of taxes on economic growth is negative and significant, and for an increase in the rate of corporate tax rate, business tax rate and indirect taxes rate by $2 / 4$ and $2 / 8$ and $1 / 8$ of economic growth is reduced. The results also reflect the positive impact of population growth rate, trade openness rate and the negative impact of inflation rate on economic growth in Iran.
\end{abstract}

Keywords: Corporate Income Tax Rates, Business Tax Rates, Indirect Tax Rates, Economic Growth Rate

\section{Introduction}

Taxes has long been regarded as an important source of government incomes and Apart from income duties, other important tasks, including economic stabilization, social welfare, security, Justice, through proper distribution of wealth that are included in the macro-economic targets. Additionally, the tax is considered an important tool of government policy. Tax, like other developing countries or the Persian Gulf in Iran could not play a significant role in the economy and the tax system inefficient due to the presence of oil revenues and it's strong role in the economy [17].

In Iran tax is the second main source of income after oil revenues. According to the figures of national treasury of Iran, the share of taxes in the budget of the years 2009 and 2010 respectively around 28 and 22 percent and the share of taxes in GDP by about 5.4 and 5.5 percent, although compared to many developed countries less but a significant figure in the country's economy.

States in terms of economic intervention based on theories such as Keynesian economics, classics and etc have important economic role and are responsible for monetary and financial policies, such as determining the tax base and tax rate optimization, investment, research and development, and the creation of appropriate infrastructure, provide economic growth. Tax rates, in a broad-based economic system, adverse effects on the economy will be different. So set tax rates should be set to leave the least impact damage to the economic system [11]. In this regard, several studies such as Hamburg [10] and Saez [25] to determine the optimal tax rate and the impact of these variables on economic variables and maximize the efficiency of the tax system has been made.

One of the goals of economic growth and the undeniable impact on improving people's welfare is. Therefor, factors affecting economic growth and how that growth is affected by government policies Has always been stressed. Since in recent years the Iranian government to reform the tax structure and the introduction of new tax base like VAT, in this study, we try to make the connection between the growth rates of tax and gross national product and thus economic review.

In this article, after the section, below the theoretical foundations, research records and also pays model and analyze the results, and the conclusions and recommendations offered.

\section{Theoretical Foundations of Research}

\subsection{Types of Taxes}

Direct taxes and indirect taxes can be divided into two categories: 


\subsubsection{Direct Taxes}

The type of tax is directly proportional to income, assets or wealth of individuals and companies, according to the Tax low gets from different rates that it consist of two groups of income tax and property tax or wealth.

A) Property tax, including inheritance tax, empty buildings tax, annual state tax, stamp duty ets is.

B) Income tax, including tax on income from rent of states, income tax on wages, corporate income tax, business income tax and income tax of accidental.

This type of tax is not transferable and shall be levied according to ability to pay, why correspond with the Tax Justice (if a person have no income then will pay no tax, but have consumption and have to pay VAT tax). Since, taxes on empty houses, agriculture and annual state is deleted from the Iran tax law, Applied rates, except for some items such as corporates that are fixed or stamp that is fixed fee, are progressively and will rise with rising of basis from $15 \%$ to $35 \%$.

\subsubsection{Indirect Taxes}

The value of some goods and services by applying different rates added and the consumer is taxed. the people who have more consumption have more taxes . Unlike direct taxes, this kind of tax is transferable and on the basis of ability to pay is not set. Indirect taxes classified in following:

A) customs duties and commercial benefit (taxes on imports and exports) which aims to preserve and support the production and domestic resources and revenue passed

B) consumption tax and sales tax, which includes retail, wholesale, petroleum, drinking, alcohol, cigarette and tobacco sales, etc

The types of taxes under the law of aggregation tax and at a rate of $3 \%$ ( $2 \%$ government tax and $1 \%$ municipal tax $)$ was collected from 2003 to first half of 2008 . According to the fifth plan of economic development of Iran, in the second half of 2008 under the law of VAT with the base rate of $3 \%$, each year, one percentage point will rise to $7 \%$. According to the Act of Parliament a percentage allocated for education and health has increased to $8 \%$ in 2014 [6].

\subsection{Different Views of Theorists}

Taxes, including those that are agreed upon various schools such as Mrkantlyzm, physiocrats, classical and what is disputed is how to collect and how it is to meet a variety of tasks. in a classical background, growth simply is dependent on factors such as physical and human capital, But after the formation of endogenous growth models, many researchers have studied the role of tax policy and economic growth and have reached different conclusions.

\subsubsection{Classic View}

Adam Smith's Wealth of Nations last part of the book is devoted to public finance and an extensive literature about the levy after Smith emerged. Classical economists believed that the economy automatically adjusts with full employment status and did not need to implement stabilization policies and government spending to tax is limited to the duties of the order, security, and social justice apply sovereign duties and defensive act.
The tax impact from two perspectives classic impact on the supply and demand impact can be studied:

According to this group, with lower taxes on labor income, labor supply increased impetus as a result of labor supply and subsequently increase production. Another important issue was whether government spending can impact on aggregate demand or not? If the government to finance itself in the form of increasing taxes and expense them as subsidies, grants, etc, the purchasing power of people has increased and therefore the total demand will increase, But on the other hand, in terms of tax increases, income, purchasing power and therefore reduced the demand of people, aggregate demand and, consequently, the effectiveness of spending on aggregate demand by increasing taxes on aggregate demand is neutral, So fiscal policy impact(increase the tax) will has no impact on aggregate demand [28].

\subsubsection{Monetarist View}

According to this group, government provides it's expenditure from three ways: raising taxes, selling bonds to the public and borrowing from the central bank. In this case, monetarist financial policy is similar to the classic and believe if government spending by raising taxes or selling bonds to the public supply, increasing government spending almost as much to reduce private sector spending, that is, those higher taxes, will pay less consumer goods, As a result, government spending will not have a significant impact on production and employment.

\subsubsection{Keynesian View}

Keynesian is theory of the total spending in the economy (which is called aggregate demand) and its effects on output and inflation. Keynesian believe that aggregate demand affect economic decisions of public and the private and public economic decisions on monetary and fiscal policy (government spending and tax) will be done. Now almost all Keynesians and supporters of monetarism believe that monetary and fiscal policy on aggregate demand affect and both using the IS-LM curves suggest that the increase in government spending, aggregate demand increases directly and increases product and according to the positivity of the marginal propensity to consume leads to an increase in private consumption is .Keynes's view, the reduction of government spending (fiscal policy tightening) has a negative impact on private demand and production and since consumption is the largest component of aggregate demand, private consumption also has a negative impact. If with government spending and cutting taxes (expansionary policy), private consumption due to high disposable income increased, it can be said that fiscal policy has Keynesian nature [23].

\subsection{The Impact of Taxes on Economic Growth from the Supply Side Perspective}

By multiplying the taxable tax base (income, prices of goods and services) in the tax rate is obtained $(\mathrm{T}=\mathrm{tY})$, so the tax revenue directly related to these two factors, of course, always respect each rate tax will further increase tax revenue is not established. American economist Arthur Laffer curve in the late 1970s in the name of its famous supply-side 
economics had a profound influence on the development of thought offered.

Laffer Curve-

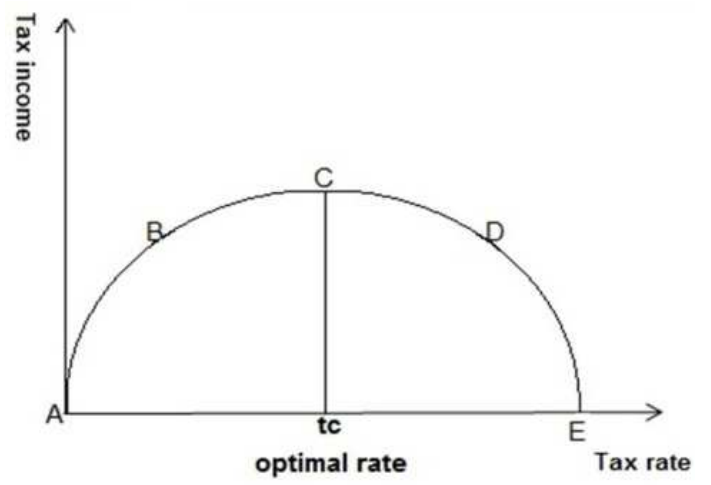

Figure 1. Laffer curve.

The Laffer Curve is based on this hypothesis, Up to a certain point of tax rates, economic activity and thus the basis of tax rates show a positive reaction, but without tension and The rate increases to this amount, no negative impact on profitable activities. Despite the steep progressive rates, the basis of taxation and economic activities approaching the rate (tc) show a negative reaction. As can be seen in the form of government in the A, E, the starting and ending points of the curve, which represents a tax rate of zero and one hundred percent not have any income. This means that if the tax rate is zero percent will not be any taxable income and tax revenue will not exist and if the rate is one hundred percent of all income shall be confiscated by the government and there will be no incentive to work tax sources will be lost. The two point $\mathrm{A}$ to point $\mathrm{C}$ of the aforementioned increase in tax rates increased tax revenue and from point $\mathrm{C}$ to point $\mathrm{E}$ will reduce tax revenue. If the government decides to reduce tax rates and the rates at the time point $\mathrm{B}$, economy will move to the left on curve, tax revenue decline and so when the decision of the curve In order to reduce the tax rate is at point $\mathrm{D}$, the economy will be on the curve to the left, but this time in economic activity will increase tax revenue. The important point is that GDP always will be more with low tax rates than high tax rates (between $\mathrm{A}$ and $\mathrm{C}$ ), because by increasing tax rates more than tc, economic activity reaction negative [1].

\subsection{The Impact of Taxes on Economic Growth in the Demand Outlook}

Any changes in taxes or public expenditure called fiscal policy statement. the government has taken any expansionary fiscal policies (spending or tax cuts) or tightening (spending cuts or tax increases) due to recession or inflation, aggregate demand under affects. In this view, in order to increase production and reduce inflation, fiscal policy and taxes are effective and can be used as a factor for macroeconomic balance through demand management, play a significant role. Consumer spending and private investment in the field of tax policy is of the highest importance. Tax the marginal propensity to consume by reducing the multiplier factor, reducing the volume of demand implications. The indirect taxes or a tax on consumption of goods and services is an example of this approach. This means that the tax on consumption of goods and services in the demand for consumption decreases and lower demand, reducing the incentive to produce and thus reduce the growth would be [17].

In Iran, among the total income tax, value added tax after tax on companies, is the second position. Those for which the tax at all stages of production, distribution and sale of applied and transferred to the final consumer and capital goods are not entitled to apply such legislation on capital goods investment is encouraged. In order to support domestic production and stimulate more production and exports of goods and services for export of goods and services intended rate is zero. In this case, in addition to the tax credit, a tax credit equal to the amount paid for purchased inputs is also intended for the exporter. In contrast, import of goods and services on the law is taxable in compliance with the protection of domestic production and expanding trade surplus is imposed.

Aside from the above, VAT on consumption and savings of individuals and businesses affected, and to reduce consumption, increase savings and investment incentive is, of course, the negative consequences of such a law can affect property the general level of prices, stated that due to lack of proper implementation of the law could lead to higher prices and thus inflation [2]. This research under Praken (1986) studied the case that VAT in the long term, increase savings and production will follow the whole production tends to decrease in the short term.

\subsection{Resources and Statistics}

Economic indicators for assessing the efficiency of the tax system in the economy, the ratio of tax to total tax revenue each tax source or any source of tax on gross domestic product, each of which gives a good indication. Because businesses and individuals tax rates in accordance with Article 131 of direct taxes law of Iran, and exponentially proportional to income, from 1981 to 2001, only four times have been changed by Parliament and the corporate income tax rate from 2001 to the The last direct tax reform has a fixed rate of $25 \%$ on corporate profits has been set. Therefore, for more efficiency the ratio of tax revenue to GDP in each year as tax rates have been used.

\section{Literature}

Rajabi et al [22], in a study entitled "Analysis of the effect of tax rates on economic growth in the years 1973-2007" examines the role of tax rates on economic growth using time series information to the Central Bank and with regard to the system synchronization of the overall economic balance of the three-stage least squares method (3sls) have studied. The results suggest that the impact of tax rates on economic growth is negative and they vary inversely with each other. In order to increase economic growth, tax rates should be reduced and policy makers so that the maximum growth rate to have.

Shafiee \& Boromand [24], in an article entitled "Study The impact of fiscal policy on economic growth" to assess the 
effects on economic growth of governmen expenditure and taxes paid during the years 1959-2003. The results show that among the government structural costs, government current costs and taxes, the structural costs more effective and direct role in economic growth and ongoing costs has no impact on economic growth, and taxes adverse effect on the economic growth.

Tari \& Sattari [26], in an article entitled "The effect of government expenditure and taxes on economic growth in OPEC" using AK endogenous growth model using panel data techniques, such as the effect of government spending, taxes, oil prices on economic growth and development of human resources in the OPEC countries examined have a time period 1998-1970. Estimation results show that the negative effect of government spending and oil prices on economic growth and has been of great significance, but it couldn't show an exact impact of taxes.

Karas \& Fursry [14], in an article entitled "Taxes and Economic Growth in Europe" (2009) examined the role of tax rates on economic growth in 19 European countries have over the years 1965-2003. The study shows that the impact of taxes increase in per capita GDP is negative and indicates that an increase in the tax rate of around 1, GDP (ratio of total tax to GDP) has a long-term effect of $-/ 5 \%$ - to $-1 \%$ the real GDP per capita. The findings also show that the increase in social security duties or taxes on goods and services have a negative effect on per capita GDP greater than the increase in tax revenue.

Lee and Gordon [14], in an article entitled "tax structure and economic growth", the role of corporate tax rates, personal income tax and consumption tax on goods and services have on economic growth in 70 countries over the period 1970-1997. The main practical strategy, the search for extra-financial impact on per capita GDP growth using crosssectional data set of countries. Estimates indicate that the corporate tax rate lead to lower future growth rates within countries. The coefficient estimates suggest that a cut in the corporate tax rate by 10 percentage point will raise the annual growth rate by one to two percentage point.

\section{Structure Model and Estimates}

\subsection{Structure Model}

To describe the model, the Cobb-Douglas production function is used when the per capita production as (1) is

$$
F_{t}\left(k_{t}\right)=a_{t} k_{t}^{\alpha} h_{t}^{\beta} \mathrm{e}
$$

Where $\mathrm{k}$ denotes capital/labor ratio and $\mathrm{h}$ is average human capital per worker.

The growth rate of the production function is (2)

$$
f / f=\mathrm{a}+\alpha(\dot{\mathrm{k}} / \mathrm{k})+\beta(\cdot \mathrm{h} / \mathrm{h})+\dot{\eta}
$$

Any productivity growth brought about by entrepreneurial activity should show up in á, so the effects of tax rates on entrepreneurial activity show up here. The $\mathrm{k} / \mathrm{k}$ and $\mathrm{h} / \mathrm{h}$ in equation (2) by changes in the ratio of capital/labor and is education of labor. $\eta$ any unstable cyclical changes in production that originally may have tax rates that relationship. The basic model is (3)

$$
G r_{i}=B_{0}+B_{1} T T+B_{2} T_{i}+B_{3} S_{i}+B_{4} D 67+X_{y}+e_{i}
$$

In the above equation: Gri, Iran's per capita GDP growth rates for the years1981-2010, TT corporate tax rate (corporate income tax revenue share in GDP), Ti business tax rate (business tax revenue share in GDP), Si indirect tax rate (the share of indirect tax revenues to GDP) is the sum of income from income tax on the consumption of excise goods and services and taxes on imports are obtained, D67 ,dummy variable for the number of years and other years is a zero. Xy control variable that includes 1-population growth rate $(\mathrm{P}) 2$ average rate of inflation $(\mathrm{F}) 3$ - trade openness rate $(\mathrm{H})$.

Before estimating the model, the Augmented DickeyFuller test (ADF) for stationary of the variables used. In this test, rejection of zero assumption, indicates the stationary of each variable in meaningful level. If modulus of test is bigger than modulus of critical value, then slightly variable is stationary. The variables, corporate tax rate, business tax rate, indirect taxes rate and the average inflation rate is stationary of the order of one or I (1) and growth rate of GDP per capita Iran, the population growth rate and trade openness stationary or I (0) Are.

So must the method used to estimate the model variables have a cumulative time zero and one without problem together are so used to estimate the model ARDL used.

Crisis and shocks in the economy of any country like war, oil shocks, etc., can affect macroeconomic variables and variables may not static or structural failures due to shock to them, So for years that structural failure occurred Peron's structural performance and results of structural failure that caused the change in the intercept and the slope of the trend is due to the fact that the modulus value $t p^{\wedge}$ calculation of modulus $t p^{\wedge}$ table at 5\% less, the hypothesis is not rejected, resulting in a static variable corporate tax rate $(\mathrm{TT})$, business tax rate $(\mathrm{Ti})$, indirect taxes rate $(\mathrm{Si})$ and the average inflation rate $(\mathrm{F})$ is rejected at 5 percent. So the reason of nonstationary of variables is not the shock applied on the model. The classical assumption Test Results (Dorbin Watson, etc.) by application Macrofite shows, the number in brackets because more than 5\%, statistically significant and there is no reason to reject the null hypothesis.so The models with serial correlation problems, functional form (specified models), normality and heteroscedasticity, not face.

\subsection{Model Estimate}

The results of the Auto Regressive Distributed Lags (ARDL) for the growth rate of GDP per capita over the period 1981-2010 using software Macrofite in the table 1 is. Schwarz Bayesian criterion (SBC) is used in selecting the optimal model has fewer degrees of freedom is lost. To determine the optimal number of lags rod variables in the model due to the small sample size used Schwartz Bayesian criterion. Based on the best model software is considered the most optimal lag. After determining the optimal number of each of the variables can be long-term relationships to achieve short term economic growth pattern. 
Table 1. The results of Auto Regressive Distributed Lags ARDL $(0,1,1,1,0,1,0)$.

\begin{tabular}{lllll}
\hline Variable name & symbol & coefficient & Standard deviation & T-Ratio[Prob] \\
\hline Corporate tax rate & $\mathrm{TT}$ & $0 / 34$ & $1 / 12$ & $0 / 30(0 / 76)$ \\
Corporate tax rate with a lag & $\mathrm{TT}(-1)$ & $-2 / 65$ & $1 / 32$ & $-1 / 99(0 / 06)$ \\
Business tax rate & $\mathrm{T}$ & $-2 / 78$ & $0 / 85$ & $-3 / 26(0 / 00)$ \\
Indirect tax rates & $\mathrm{S}$ & $4 / 93$ & $2 / 40$ & $2 / 05(0 / 05)$ \\
Indirect tax rates with a lag & $\mathrm{S}(-1)$ & $-6 / 14$ & $1 / 64$ & $-3 / 72(0 / 00)$ \\
Trade openness & $\mathrm{H}$ & $0 / 46$ & $0 / 17$ & $2 / 60(0 / 01)$ \\
Average of Inflation rate & $\mathrm{F}$ & $-0 / 16$ & $0 / 04$ & $-3 / 62(0 / 00)$ \\
Population Growth rate & $\mathrm{P}$ & $-6 / 25$ & $4 / 62$ & $-1 / 35(0 / 19)$ \\
Population Growth rate with a lag & $\mathrm{P}(-1)$ & $8 / 40$ & $3 / 51$ & $2 / 39(0 / 04)$ \\
Dummy variables (8 years war) & $\mathrm{D} 67$ & $2 / 90$ & $6 / 46$ & $0 / 44(0 / 66)$ \\
Dummy variables with a lag & $\mathrm{D} 67(-1)$ & $-12 / 10$ & $5 / 74$ & $-2 / 10(0 / 05)$ \\
Intercept & $\mathrm{C}$ & $-8 / 46$ & $19 / 2$ & $-0 / 44(0 / 66)$ \\
Trend & $\mathrm{Trend}$ & $-0 / 60$ & $0 / 32$ & $-1 / 86(0 / 08)$ \\
Diagnostic tests & $\mathrm{DW}=2 / 1$ & $\mathrm{R}^{2}=/ 82$ & $\bar{R}^{2}=/ 68$ & $\mathrm{~F}=6 / 08(/ 001)$ \\
\hline
\end{tabular}

Source: Findings

Estimated short-term shows, variables of tax rates for corporate tax rate and indirect tax rate with a lag and in confidence level of 94 percent and business tax rate and the average rate of inflation in a significant, negative impact on the growth rate of GDP per capita there. Estimated short-term also positive impact of trade openness and growth rate of the population (with a lag) on the growth rate of GDP per capita there.

\subsubsection{Evaluation of Long-Term Equilibrium Relation of Test}

In general, the economic concept of co-integration, represents a long-run equilibrium relationship between two or more series of time. Because long-term coefficients model without ensuring the long-term equilibrium relationship between the variables are not allowed to test for the presence or absence of an approach long-term relationship between the variables, regardless of the regression of the I (0) or I (1) One of the methods used to co-integration, Pesaran and et al cointegration test [19].

Table 2. Some test results to assess the long-term relationship.

\begin{tabular}{llll}
\hline \multirow{2}{*}{ The statistics } & \multicolumn{2}{l}{$\mathbf{9 9 \%}$ confidence level } & Result \\
\cline { 2 - 3 } & $\mathbf{I}(\mathbf{0})$ & I(1) & \\
\hline The statistics of $\mathrm{F}$ & $3 / 41$ & $4 / 69$ & Long-term relationship \\
\hline
\end{tabular}

Resource: findings

According to the results table 2, F statistic for significance test levels lagged variables in the form of error correction is tested. The $\mathrm{F}$ statistic significance test calculation for all coefficients equal to 6.14 is obtained. Due to the variables in the model of zero and one are still far, so it should be an upper limit beyond $\mathrm{F}$ computing. The upper and lower critical value of $F$ statistic in the model has a width of source and process for a confidence level of 99 per cent, respectively 4.69 and 3.41 are. As a result of the rejection of the null hypothesis that there is no long-run relationship between the variables and long-term relationship between the variables of the model will be accepted.

\subsubsection{Estimate the Long-Term Pattern}

According to long-run equilibrium relationship, long-term pattern Table 3 is estimated.

Table 3. Measure of long-term.

\begin{tabular}{|c|c|c|c|c|}
\hline Variables name & symbol & coefficient & $\begin{array}{l}\text { Standard } \\
\text { deviation }\end{array}$ & $\begin{array}{l}\text { T-Ratio } \\
\text { [Prob] }\end{array}$ \\
\hline $\begin{array}{l}\text { Corporate tax } \\
\text { rate }\end{array}$ & TT & $-2 / 37$ & $1 / 08$ & $-2 / 19(0 / 041)$ \\
\hline Business tax rate & $\mathrm{T}$ & $-2 / 78$ & $0 / 85$ & $-3 / 26(0 / 00)$ \\
\hline Indirect tax rate & $\mathrm{S}$ & $-1 / 8$ & $0 / 82$ & $-2 / 18(. / 04)$ \\
\hline Trade openness & $\mathrm{H}$ & $0 / 46$ & $0 / 17$ & 2/60(./019) \\
\hline $\begin{array}{l}\text { Average } \\
\text { inflation rate }\end{array}$ & $\mathrm{F}$ & $-0 / 16$ & $0 / 04$ & $-3 / 62(. / 00)$ \\
\hline $\begin{array}{l}\text { Population } \\
\text { growth rate }\end{array}$ & $\mathrm{P}$ & $5 / 15$ & $2 / 10$ & $2 / 44(0 / 036)$ \\
\hline Dummy variable & D67 & $-9 / 20$ & $3 / 32$ & $-2 / 76(0 / 007)$ \\
\hline $\begin{array}{l}\text { Intercept without } \\
\text { trend }\end{array}$ & $\mathrm{C}$ & $-8 / 46$ & $19 / 20$ & $-0 / 44(0 / 66)$ \\
\hline $\begin{array}{l}\text { Intercept with } \\
\text { trend }\end{array}$ & Trend & $-0 / 60$ & $0 / 32$ & $-1 / 86(0 / 08)$ \\
\hline
\end{tabular}

Resource: findings

As Table 3 shows, corporate tax rate coefficients are statistically significant and negative impact on GDP per capita growth rate, so with one unit increase in corporate tax rate, Iran's per capita GDP growth rate decreased 2.37 units. Research such as Hubbard and Gentry (2000) and Gordon (1998), showed that progressive rates of businesses tax rates, reduce investment risks or destroys.

Business income tax rate is statistically significant and negative impact on GDP per capita growth rate, so an increase of one unit in the business income tax rate, the growth rate of per capita GDP decreased by 2.7 units. Kaldora believes that the income tax has negative impact on saving but just the revenue progressively more favorable. Progressive tax rates to reduce relative incomes of highincome jobs than others and more appropriate distribution of income, which results in reduced consumption and savings of 
the poor people will be more than. Since almost all the savings made by the same people, thus reducing the impact on savings would be significant. Research also suggests in this regard, the negative impact of the increase in this type of tax on economic growth and thus reduce the incentive for individuals to operate their businesses.

Indirect tax rates are statistically significant and negative effect on the growth rate of GDP per capita, ie an increase of one unit in the rate of indirect taxes, the growth rate of GDP per capita in the 1.8 unit is reduced. In fact, apply tax on consumption of goods and services are of the view that to impose a tax on consumption of goods and services the demand for people to use consumer welfare as a result of reduced demand and reduce the incentive to reduce production and reduce the causes growth.

Population growth rate coefficient is statistically significant and positive impact on the growth rate of GDP per capita, ie with an increase of one unit in the population growth rate, the growth rate of GDP per capita increased by 5.15 units And based on the "golden rule of" we can say that the marginal efficiency of capital is equal to the rate of population growth, economic growth is a direct function of population growth rate. Countries with high population growth of less developed countries, mostly low economic growth in developed countries and advanced-educated work force is considered an important factor in economic growth. With the increase in transaction costs and increase the cost of living as a result of reduced economic growth, reduce investment in productive activities.

Trade openness coefficient is statistically significant and positive impact on the growth rate of GDP per capita, ie with an increase of one unit in the degree of openness of trade, the growth rate of GDP per capita could increase by as much as. 46 unit the foreign trade by improving the allocation of resources, access to technology, increasing domestic competition and innovation creates the perfect environment to have a positive effect on GDP per capita growth rate.

Dummy variable statistically significant factor related to the war and its negative sign indicates a negative effect on the growth rate of GDP per capita Iran.

\section{Conclusion and Suggestions}

\subsection{Conclusion}

In this study, using ARDL and using Eviews software and Microfit the short term and long term impacts of three tax rates (corporate tax rate, businesses tax rate, indirect tax rate) and some other related variables on economic growth rate of Iran, using time series and Statistics Central Bank during the 30-year period studied. Firstly, short-term relationships between the variables studied, then after establishing longterm relationships by using, Pesaran and et al co-integration test examined. In each of relationships, each of the three types of tax rates for basic have a negative impact on economic growth that in each tests, the impact of each of the three types of tax rates on economic growth rate was Significant and negative. Moreover, results also reflect the positive impact of population growth rate, trade openness rate and the negative impact of inflation rate on economic growth rate in Iran.

\subsection{Suggestions}

1-According to the Cobb-Douglas production function, one of the most important items affecting economic growth, labor force and a large part of the population are merchants. However, the share of business tax in total tax revenues despite the large number of workers, 7 per cent and its share of gross domestic production of about 4 Percent, a very low figure compared to other tax sources and had a significant negative impact on economic growth. Despite recent amendments to the tax rates on direct taxes law in 2001, leading to reduction of progressive business tax rates, according to statistics, much increase in the share of this type of tax has not come. Therefore, it is suggested that the government consider the Laffer Curve, tax rates to determine a way to create incentives to work and invest, the greatest revenue impact on macroeconomic variables and therefore have economic growth. It is also proposed to reduce the cost and increase tax revenues, taxpayers subject to business tax paragraph (ج) of Article 95 Direct Taxes law that the bulk of time and manpower in this type of tax is allocated to be removed and in parts of the corporate income tax and indirect taxes (VAT) applied.

2-Due to the negative impact of inflation on economic growth rise to conditions of uncertainty and high risk investors, the government should identify the factors associated with inflation and fiscal and monetary policies to reduce or control inflation and continued economic growth act.

3-According to the classification of Heritage Foundation's annual statistics, Iran is one of the world that has the closed economy, Therefore, it is proposed that the government consider the interests of domestic production, tariffs and trade with other countries, especially developed to be set so that investment and science and technology entry into the country to facilitate and provide economic growth.

\section{References}

[1] Alaa E, (1994), "Finance optimal use of Laffer Curve", Journal of Finance, 5, PP: 8-9.

[2] Bureau of economic Research, (2005), VAT and its advantages and disadvantages, vol 7471.

[3] Direct Tax Law (adopted 03.12.1366 11.27.1380 approved the last amendments) and the Law on VAT.

[4] Dadgar Y, (2008), "Barrow model to assess the relationship between inflation and economic growth", Journal Economic Research, pp: 64-64.

[5] Engen E \& Skinner S, (1996), Taxation and economic growth", National Tax Journal, vol 49, no 4, pp: 4-617.

[6] Fifth Economic development plan of Iran, (2010), Article 117, Cluse 2.

[7] Gerami M, (2011), "reviews tax rates in some countries and compare it with Iran", Economic Journal, 43.

[8] Gregory N. mnkyv, macroeconomic, translating HR Brothers (1995), University of Allameh Tabatabai. 
[9] Hamburg, Stefan, (2004), "A New approach to optimal commodity taxation" Discussion paper, No.299.

[10] Hejabr Kaviani K, (2013), "Calculation of optimal tax rates of individuals and companies", Journal of tax research, No 6, pp: $7-40$.

[11] Jaafari A \& Hasanzadeh A, (2005), "The effect of taxes on economic growth: A review of theoretical and empirical analysis", Journal of Economic Research, 1 (2), PP: 41-67.

[12] Journal of Taxation, Department of Economic Affairs, various numbers.

[13] Karras G \& Furser D, (2009). "Taxes and growth in euorope. South-Eastern.

[14] Karbasi A, (2009), "The process of trade liberalization in Iran during 1972-2001", Journal of knowledge and Development, pp: $149-159$.

[15] Lucas, R. E. (1998). "On the mechanics of economic development, Journal of Monetary Economics 2, pp: 3-24.

[16] MehnatfarJ \& others, (2007), "Assessing the economic impact of tax revenues to the government's current spending: An Empirical Analysis (1978-2004)", Journal of Economic Research Shmarh, 43, pp: 78-104.

[17] Nikki Oskoee K, (2009), "The Role of taxes in the budget deficit fluctuations" .journal of taxation, 5 .

[18] Office of Economic Studies, (2009), "VAT and its advantages and disadvantages".

[19] Pesaran H \& Shin, (1997), "An Autoregresive Distributed Lag Modelling Approch to CointegrationAnalaysis", Department of Applied Economics, University of Cambridge, England, pp: 16-17.
[20] Qtmyry \& others, (2006), "The effect of government expenditure and its financing resources on GDP and economic growth: the IRA in the years 1967- 2003", Journal of Economic Research Shmarh, 43, pp: 6-29.

[21] Romer P. M, (1987), Growth based on increasing returns to specialistion. Journal of Political econimey, 94, pp: 10021037.

[22] Rajabi M \& Ibn Ibrahim M, (2011), "Analysis of the effect of tax rates on economic growth-period from 1973 to 2007", Kerman, International Conference on Economic Jihad, pp: 1-12.

[23] Samadi A, (2011), "Assessing the nature of fiscal policy and reviews property Rftaradvary" Economic Essays Fsanamh .16, pp: 56.

[24] Shafii A \&Boromand SH, (2006), "test the impact of fiscal policy on economic growth", Economic Research Journal, 33 (5), PP: 153-181.

[25] Saez E, (2001), "Using elasticities to derive optimal income tax rates" Review of economic studies, vol.68, pp 205-229.

[26] Stari R \& Tari F, (2005), "The effect of government expenditure and taxes on economic growth in OPEC countries", Economic Journal, 16 (5), PP: 182-153.

[27] Taghavi M, (1994), Macroeconomics, Press PNU.

[28] Taghavi M, (1991), "Taxation and Economic Growth Rate in Iran", Journal of Public Administration, 13, pp: 74-89.

[29] Young Lee, \& Roger H. G, (2005). "Tax structure and economic growth", journal of public economic, 89, pp: 10271043. 